PR

37,3

332

Received 23 September 2005

Revised 30 March 2007

Accepted 3 May 2007

\section{Flexibility through HRM in management consulting firms}

\author{
Ana Carvalho and Carlos Cabral-Cardoso
}

Department of Management, University of Minho, Braga, Portugal

\section{Abstract}

Purpose - This paper aims to examine how functional and numerical flexibility can be successfully combined without workforce segmentation or flexible employment contracts, by implementing a highly integrated human resource management (HRM) system.

Design/methodology/approach - Six case studies were conducted between January 2002 and June 2003 in Portuguese affiliates of multinational management consulting firms using a grounded theory approach.

Findings - Evidence from the case studies showed that some of these companies were able to explore both functional and numerical flexibility in a combined and interdependent way, by operating a tightly run and highly coordinated set of HRM practices geared towards the development of internal labour markets.

Research limitations/implications - The study uses a sample of large multinational companies in a single sector, which limits the scope of these findings.

Practical implications - It is suggested that a strategy combining numerical and functional flexibility through an integrated set of HRM policies and practices will be more effective than segmenting the workforce or choosing between those two sources of flexibility.

Originality/value - The paper presents a new breadth for the role of HRM in achieving flexibility. Theoretically, it challenges the established notion that commitment-based HRM serves only functional flexibility and that numerical flexibility can only be achieved through precarious employment.

Keywords Human resource management, Skills flexibility, Numerical flexibility, Management consultancy, Case studies

Paper type Research paper

\section{Introduction}

The concept of employment flexibility features prominently in most models of HRM (Sisson and Storey, 2000; Guest, 2001) and operating different kinds of flexibility seems to have direct and inevitable impact on the management of people in organisations (Gallie and White, 1994; Rubery, 1994; Knox and Walsh, 2005). Although widely recognised (Blyton and Morris, 1992; Kalleberg, 2001; Larsen and Mayrhofer, 2006), the role of human resource management in employment flexibility is far from clearly understood.

Functional and numerical flexibility tend to be viewed as alternative sources of flexibility. The rationale for this is based on the fact that these two flexibility strategies underlie distinct approaches to the management of people, the former favouring a long-term mutual investment employment relationship and the latter looking to minimise costs and mutual attachment. Thus, functional flexibility is usually associated with commitment-oriented HRM systems whereas numerical flexibility is related to a hard approach to HRM.
Personnel Review Vol. 37 No. 3, 2008 pp. $332-349$

() Emerald Group Publishing Limited 0048-3486

DOI $10.1108 / 00483480810862305$ 
Suggestions have been made for combining these two types of flexibility in the same firm. The most influential approach is the internal core-periphery segmentation of the workforce. Kalleberg (2001, p. 489) identifies two other promising perspectives, namely the use of human resource portfolios, and the use of external organisational networks, though both assume some kind of segmentation of the workforce and the implementation of differentiated HRM systems. In contrast to these proposals, this paper seeks to demonstrate that functional and numerical flexibility can be explored simultaneously and interdependently. In particular, numerical flexibility can be achieved without workforce segmentation or the commonly associated non-standard employment arrangements. Moreover, the two kinds of flexibility can result from operating a single HRM system instead of adopting different HRM systems for different flexibility goals.

\section{Employment flexibility and HRM}

Flexibility is an ambiguous and ill-defined concept (Blyton and Morris, 1992; Mayne et al., 1996). The flexibility debate tends to concentrate on the notions of functional and numerical flexibility and the implications of adopting either one or the other. Functional flexibility is usually seen as the ability to respond to changes in business needs by having multi-skilled, adaptable and internally mobile employees (Atkinson, 1987; Blyton and Morris, 1992; Sparrow and Marchington, 1998). It requires a skilled and committed workforce that can only be achieved by investing in training and long-term employment relationships and is, therefore, connected with the establishment of internal labour markets and primary sector employment. Numerical flexibility, on the other hand, is the ability of the firm to vary the quantity of work employed to match changes in the business needs (Atkinson, 1987; Blyton and Morris, 1992; Sparrow and Marchington, 1998). It represents a cost-cutting approach that looks to externalise the employment relationship, and is associated with short-term and precarious employment conditions in the secondary labour market segment, under which workers have little incentive or opportunity to be functionally flexible.

Two different perspectives can be detected in the literature as to whether numerical and functional flexibility are alternative or complementary (Cappelli and Neumark, 2004). The former view sees them as opposing strategies that are essentially contradictory and irreconcilable in the same organisation. Such a view leads to "dual" or "segmentation" theories (Gallie and White, 1994) that propose the segmentation of the labour market into a primary sector of "good jobs" and a secondary sector of "bad jobs". Firms will choose between the two, depending on factors such as technology, size, management control systems and trade union influence (O'Reilly, 1992; Gallie and White, 1994; Rubery, 1994; Smith, 1994).

However, the complementary perspective seems to be gaining acceptance, recognizing the organisations' need for "multiple and parallel flexibilities" (Sparrow, 1998), especially in a time of increasing international competition and technological change (Atkinson, 1987; Tsui et al., 1995). The much acclaimed and policy informing model of the flexible-firm, by Atkinson (1987) is one of such conciliating proposals suggesting firms can simultaneously exploit different kinds of flexibility by segmenting their own workforce into a core of long-term committed employees hired under attractive internal labour market conditions, and a periphery of short-term and

\section{Flexibility through HRM}

333 
PR

37,3

334

contingent workers contracted under more precarious market-determined conditions (Atkinson, 1987; Gallie and White, 1994). Functional flexibility can be developed among core employees while peripheral workers secure numerical flexibility.

This model has received much criticism from theoretical, methodological and ideological stances (MacInnes, 1988; Pollert, 1988; O’Reilly, 1992; Hunter et al., 1993; Legge, 1995). An issue that has been overlooked in the model relates to HRM. Although it is implied that different approaches should be used to manage core and peripheral employees, the specific HRM policies and practices to be followed are not addressed, nor are the consequences of running different HR systems in the same firm.

More recent proposals within the complementary perspective suggest the use of "human resource portfolios" (Kalleberg, 2001) as a means of combining seemingly contradictory kinds of flexibility within the same organisation. And Tsui et al. (1995) suggest a connection between different employment strategies, based on the distinction between job-focused and organisation-focused approaches, and corresponding HRM practices.

The job-focused approach reveals an apparent preference for externalising the employment relationship and is associated with the employer's desire to be flexible by adjusting its workforce to market demand. Under this approach, HRM does not require employees' commitment to long-term organisational survival and success. Obligations and rewards are clearly and explicitly defined by contract, along the lines of Walton's (1985) control strategy and Arthur's (1994) cost-reducing HR system. The organisation-focused approach, on the other hand, is designed to promote the kind of flexibility afforded by committed employees that are willing to take on different tasks, adjust their skills to new requirements and move to different locations for new assignments. The commitment of employees to the whole organisation is required in addition to their immediate job, leading firms to develop high-commitment policies and skill-based pay systems. Conceptual parallels to this approach are found, for example, in Walton's (1985) commitment strategy and in Arthur's (1994) commitment maximising HR system. Tsui et al. (1995) suggest various combinations of these two ideal types, and the use of different HRM systems in the same organisation.

Lepak and Snell (1999) present a contingent model that directly links four different HR configurations (commitment, market based, compliance and collaborative) with varying combinations of human capital, employment modes and employment relationships. While not specifically connecting flexibility and HRM, the model defines the employment mode in terms of internalisation versus externalisation along the same lines of segmentation theories. The model also draws the distinction between uses the "job-focused" and "organisation-focused" categories for the employment relationship.

These contributions help to establish more clearly the link between different kinds of employment flexibility and approaches to HRM, a relationship that is otherwise only inferred and implied by the literature (Blyton and Morris, 1992; Brown, 1997; Brewster, 1998; Friedrich et al., 1998), but seldom explicitly analysed or even stated. The pursuit of functional flexibility - either as a firm-wide strategy or a goal expected only from core employees - is associated with the internalisation of employment, the development of internal labour markets and the adoption of a soft commitment-type approach to HRM. Conversely, numerical flexibility - again, either as an employment strategy or a goal expected from a peripheral segment of the workforce - is linked to the externalisation of employment, the use of the external labour market and hard 
cost-minimising or market-oriented HRM approaches (Atkinson, 1987; Blyton and Morris, 1992; Geary, 1992; Gunnigle and Moore, 1994; Legge, 1995; Tsui et al., 1995; Lepak and Snell, 1999). However, despite the recognition of a potential organisational conflict (Tsui et al., 1995) these models tend to ignore the consequences of following parallel HRM systems.

The suggestion that different HRM systems are used in the same organisation is hard to reconcile with a commitment-based approach to HRM. Relegating part of the workforce into a peripheral status of flexible employment under disadvantaged and precarious conditions goes against the central HRM ideal of valuing people as key-resources (Blyton and Morris, 1992; Geary, 1992; Legge, 1998; Marchington and Grugulis, 2000). Supporting employment internalisation, this perspective tends to favour the pursuit of functional flexibility, considering it a more strategic approach (Rose, 1994; Rubery, 1994; Friedrich et al., 1998). However, it has also been criticised for ignoring the need for different kinds of flexibility (Gooderham and Nordhaug, 1997; Sparrow, 1998). Moreover, empirical findings such as those presented by Knox and Walsh (2005) or the ones reviewed by Cappelli and Neumark (2004) suggest the co-existence of numerical flexibility and commitment-based HRM. The implications of pursuing numerical flexibility while implementing a commitment-based HRM approach remains overlooked in the literature.

\section{The case of management consulting firms}

The literature on management consulting firms depicts them as subject to pressures that justify the need for both functional and numerical flexibilities. As knowledge-intensive firms, they depend on highly qualified and specialised professionals to offer services that result from their creative and intellectual work. Research emphasises the ambiguous, variable and ever evolving nature of this kind of work that demands versatility, adaptability and constant learning from consultants (Starbuck, 1992; Ram, 1999; Kärreman, 2002). Thus, functional flexibility appears to be a central feature of management consultancy. But this is also a highly competitive sector mainly driven by market share and service diversity (Doorewaard and Meihuizen, 2000). Management consulting firms are particularly susceptible to market variations since client demand has a direct impact on employment level and on the profile of knowledge and skills required from the workforce at any given moment (Baden-Fuller and Bateson, 1990; Boxall and Steeneveld, 1999; Alvesson, 2000; Laursen and Mahnke, 2001). This might push management consultancies to exploit numerical flexibility in order to adjust to market variations.

Yet, the strategic importance of unique, specific and valuable human capital for knowledge-intensive firms such as these would suggest a preference for employment internalisation (Matusik and Hill, 1998; Lepak and Snell, 1999). Indeed, knowledge workers are sometimes called gold-collar workers (Holland et al., 2002) due to the particularly generous employment conditions they benefit from. Some studies point to the use of progressive and innovative best practice HR policies in management consultancies in response to the major challenges of retaining these valued employees and managing knowledge creation and application (Baden-Fuller and Bateson, 1990; Alvesson, 2000; Robertson and Hammersley, 2000; Laursen and Mahnke, 2001). Other research, however, points to the growing take up of the market model in the employment of knowledge professionals and a corresponding rise in the use of 
PR

37,3

336 non-standard employment relationships (Beyers and Lindahl, 1999). Therefore, several questions persist about how management consultancies manage their workforce to attain flexibility.

This paper focuses on the flexibility strategies of management consulting firms and on how they relate to HRM. Some of the specific questions addressed are: "Do these firms pursue different types of flexibility?" "How do they deal with the incompatibilities between them?" and "What are the implications for HRM of the flexibility strategies adopted?" "Are different HRM systems run simultaneously in the same firm, and how do these firms cope with this?"

\section{Methodology}

In order to address these questions, six case studies were conducted along with a qualitative methodology. A grounded theory approach was followed due to the contradictory and inconclusive nature of theory and the scarcity of empirical research on this matter (Eisenhardt, 1989; Gummesson, 1991). Different data sources were used. Between six and 12 interviews were carried out in each firm, including interviews with: a top management representative (typically a partner) who was asked about company strategy, importance of flexibility and HRM, and influence of the international structure; the HR manager who was asked about HRM strategy, policies and practices, and the flexibility strategies pursued; a number of consultants at all stages of the career ladder who were asked about their work and responsibilities, motivations and expectations, and their experience and perceptions of HRM practices. Internal documents and reports supplied by the firms and public press releases were also analysed.

The data collected from the interviews and documents were used to inform five categories with several dimensions each (Table I) that resulted from an iterative process of combining contributions from the literature and fieldwork. Company history, business strategy and organisational structure have been identified as relevant in policy choice affecting both HRM and flexibility strategies (Delery and Doty, 1996; Tsui et al., 1995; Mayne et al., 1996; Doorewaard and Meihuizen, 2000). The role and activities pursued by the HR function and its representation at the top management level are often taken as indicators of status and strategic relevance of HRM in the firm. The policies and practices adopted also differentiate between approaches to HRM (Blyton and Morris, 1992; Truss et al., 1997). Exit management, often neglected in the study of HRM systems, was also addressed. The employment relationship including contractual details and duration prospects, and mutual expectations of both the employee and the employer may affect the motivation of consultants (Baden-Fuller and Bateson, 1990). And it is also relevant to assess the HRM approach and the flexibility strategy favoured in the firm (Blyton and Morris, 1992; Geary, 1992). Finally, the prevalence of both functional and numerical flexibilities and strategies for reconciling them were examined.

\section{Results: case studies}

The Portuguese affiliates of the six leading multinational companies in the management consulting sector were studied between January 2002 and June 2003, during which some major events affected these firms: one was taken over by a major IT corporation, and one collapsed as an international network to be later integrated 


\section{Categories}

1. Company characterisation

2. HRM department and director

3. HRM policies and practices

4. Employer/employee relationship

5. Organisational flexibility
Dimensions

Company history

Business strategy

Organisational structure

Organisational framing

Representation in top management

Image and role with consultants

Recruitment and selection

Training and development

Performance appraisal

Career management

Compensation management

Exit management

Communication

Contractual relation

Employment duration prospects

Mutual expectations about employment

Importance and prevalence of functional flexibility

Importance and prevalence of numerical flexibility

Importance and prevalence of other types of

flexibility

Ways of reconciling and consequences of different types of flexibility

\section{Flexibility through HRM}

337

Table I.

Categories and dimensions considered for data analysis

into another of the firms studied. A market crisis also afflicted the sector during that period, disturbing what the firms considered to be their "normal" line of functioning.

\section{Accenture}

The largest of the firms studied, it registered a rapid growth to the current 800 consultants. Having originated in the IT consulting unit of the Arthur Andersen group, it operated independently since 2000, and a stronger incorporation of technology differentiated their service offer. The ownership structure had recently changed from the original partnership into a PLC, but most shares remained in the hands of the former partners. The firm had a very strong identity, valuing a tight person-organisation fit, which meant that less compliant employees would feel out of place and prefer to leave. Considerable effort was also spent in building a positive image, both internally and externally.

\section{Andersen}

When the now Accenture became independent, a new Business Consulting department was created as part of a group whose main activity was in auditing. In Portugal, the company had over 1,000 employees overall. A recent financial scandal in the USA affected the company operations worldwide resulting in the collapse of the international network and brand name. During this study, the Portuguese office struggled with this crisis, but an overall spirit of confidence persisted, which was passed on to employees. An association with the smaller Deloitte \& Touche - the only other firm still combining auditing and consulting - settled the future of the former Andersen. A partnership format was kept. 
PR

37,3

338
Cap Gemini Ernst \& Young (CGEY)

This firm resulted from the acquisition by the European Cap Gemini of the consulting unit of Ernst \& Young less than two years before. This double background proved hard to overcome, being a cause of considerable diversity in how HRM was viewed and implemented. The fact that "diversity" was a value explicitly espoused by the CGEY group prolonged the normal state of confusion expected in a merger process. For example, it was thought best to keep team and leadership structures in their original units, and only gradually integrate them. This minimised the feared culture shock, but reinforced the lack of unity and consistency in how group strategy and policy were perceived and put to practice. A stagnant market and consequent fall in the demand for IT and consulting services rendered a workforce of over 500 employees oversized, and adjustments were being sought to improve the performance numbers, particularly noted in a listed company.

\section{$K P M G$}

This was the smallest firm studied, with around 80 employees, structured along the lines of a partnership. It was an independent company part of a larger group that also included auditing, financial advisory and tax services. Despite formally sharing the HRM department and policies with the group, most practices were actually locally determined by the management group and partner-in-charge. The size of the company had allowed a mostly informal treatment of situations that were starting to be felt as unsatisfactory.

\section{Deloitte \& Touche (D\&T)}

This was the second smallest firm studied, prior to integrating the former Andersen, with a partnership structure of about 400 employees among the units of auditing, consulting, tax, corporate finance and human capital. Only these two of the major multinationals still looked to keep this combination of activities within the same firm. A distinguishing feature of D\&T was that it operated mainly in Oporto (the second largest city) instead of Lisbon, which meant it worked mostly on smaller scale projects for lower fees than its competitors.

\section{PwcConsulting}

This was the management consulting unit of PriceWaterhouseCoopers. During this study, the firm was preparing its acquisition by IBM, a process that had a major impact in the organisation, guiding all actions and decisions. The need to present an attractive financial situation, as well as the uncertainty felt about the future, produced the suspension of most existing practices, including HRM. Costs were severely cut, prompting the reduction of a 200-strong workforce, and the disturbance of the overall normal functioning of the firm.

\section{HR strategy, policies and practices}

There was a remarkable similarity between the declared HRM strategies of the different firms, generally seen as deriving from business strategy and company philosophy. All but one firm intended to follow a business strategy based on achieving the widest possible market coverage in terms of services offered and business sectors served. KPMG preferred to target the smaller but "more difficult" projects that required 
more specialised attention, a feature reflected in some of its HRM choices, namely in terms of recruiting and promotion practices.

The formal definition of HR policies was also very similar among the six firms, following what was considered the latest "best practice" in HRM in the sector. Boxall and Steeneveld (1999, p. 456) have already identified this similarity between companies in the same business sector labelling it "strategic management recipes". Policy definition in all areas of management, including HRM, was decisively influenced by each firms' international structure, as these companies directly and globally compete among themselves, benchmarking against each other. Policy implementation, however, varied considerably among firms reflecting the initiative and mind-set of local leadership. The formal HRM policies and actual practices in the different firms are analysed below.

\section{Staffing}

Two main approaches to staffing emerged: recruiting mainly new graduates for junior positions, and exclusively promoting from within to senior positions; or recruiting experienced professionals only. Accenture, Andersen and D\&T favoured the former, emphasising a standardised career progression, while KPMG followed the latter. Having a smaller structure and a strategy aimed at gaining the more demanding and specialised jobs, there was no room at KPMG for junior consultants, who require training and close senior supervision. The other firms displayed hybrid approaches: at CGEY, although the official policy was to recruit only for junior positions, unexpected or unplanned HR needs led the firm to admit new entrants at all levels; PwcConsulting favoured external recruitment for both junior and senior positions, although a prospective career within the firm was still used to attract and retain consultants. At all levels of the six firms, selection was rigorous and sophisticated methods were used.

\section{Training and development}

All six firms took pride in their reputation as training grounds, though the actual training delivered varied a lot. Accenture, Andersen and D\&T directed most of their investment to formal courses designed for each career stage uniformly attended by consultants. PwcConsulting and CGEY were going through financial difficulties, which directly impacted on their training effort. Still, in the past they seemed to have combined standard courses with specific and contingent training resulting in a more uneven access to training by individuals. In KPMG, training was mainly provided by team leaders in a more informal and contingent manner, according to the specific needs identified at each particular moment in time.

Training and development fulfilled more than the obvious goal of providing employees with knowledge and skills in order to improve their performance and ability to adjust. It was also an essential element in attracting new university graduates who regarded an early placement in a multinational firm as having a beneficial effect on their careers. Not only did they acquire new and relevant skills, they also gained privileged access to potential future employers. This made young consultants particularly receptive to working hard and long hours for a couple of years. In addition, the improved employability resulting from training and development afforded these firms relative ease in dismissing consultants, who were generally acquiescent in these situations: 
PR

37,3

340
Our company is a great credential. It is regarded as a good academy of training, and if someone that has been here turns up in the market looking for a job it is usually well accepted and finds good alternatives (Top manager, Accenture).

\section{Careers}

The career track was very similar in all firms, with the vertical structure that is typical to the business consulting sector. At the initial stages, junior consultants, consultants and senior consultants (the "consulting staff") were generally responsible for the operative tasks in the projects. As consultants became managers, they assumed formal team and project management responsibilities, and took on the commercial dimension of business development. Managers might evolve into senior managers or assistant partners before actually reaching the top of the career and becoming partners of the firm and sharing its ownership and strategic command. Firms that were no longer partnerships tended to keep this career path, including the partner category, seen as an important motivational factor.

The way careers were managed, however, varied considerably across firms. In Accenture and Andersen, career advancement fitted a fairly uniform pattern. Following on the preference for recruiting into junior positions, consultants in the same entry cohort tended to be promoted simultaneously into the next career stage after receiving much the same training and work opportunities. Performance appraisal was instrumental in promotion decisions and in assigning future projects and responsibilities and assessing training needs. Consultants who found it harder to achieve high-performance levels were usually guided out rather than up the career. Firms assisted these employees with "less suitable profiles" in finding alternative placements, often in client-companies. This "up-or-out" (or "grow or go") system (Doorewaard and Meihuizen, 2000) had also been followed by PwcConsulting, although their style seemed less clear and directive. Consultants with performance below expectations were more subtly informed of their waning career opportunities by being given fewer and less interesting projects. CGEY displayed a mixed approach that reflected the different traditions of the two firms CGEY had originated from. Whereas in the former Ernst \& Young unit they were used to a fairly directive format to career progression within an "up-or-out" model, the Cap Gemini units were unaccustomed to this approach, rejected by the formal policy defined at international level. Career management was, therefore, more inconsistent and dependent on the personal views and inclinations of managers and team leaders in each unit. KPMG and D\&T formally subscribed to the "up-or-out" system, but this had a lesser practical bearing in these smaller companies, still growing rapidly and expanding their workforces.

\section{Performance appraisal}

Performance appraisal was a regular practice in every firm, usually conducted individually and on a yearly basis. In most cases, a formal approach using the multinationals' globally applied tool had only recently been adopted. The performance appraisal of consulting staff tended to combine goal achievement with the matching of skill inventories, whereas that of managers included project leadership performance and meeting business development targets. Apart from serving to identify training needs, performance appraisal was formally linked to compensation and career advancement in all the firms except CGEY. However, only in Accenture and Andersen 
was this clearly pursued, with consultants at all levels recognising and accepting it. PwcConsulting had followed this policy in the past, but career advancement and pay raises had been suspended at the time of this study. In KPMG and D\&T, the smaller firms, appraisal was still mostly an informal matter with a less straightforward impact on compensation and career. In CGEY, pay and career advancement were formally independent from performance evaluation, even though most employees seemed to expect and perceive a connection between them. The main effect of this seemed to be a disregard for the performance appraisal process seen both by consultants and their supervisors as a time consuming task without much purpose or use. The following quote illustrates this point:

I made it very clear that I will only do the performance appraisal if I know it counts for something. If I don't believe it's of any use, I won't be wasting time with it (Senior Consultant, CGEY).

Consultants in every firm were reluctant to be critical of their employer's HRM policies and practices or of their working conditions. However, performance appraisal was the area where they most freely complained, usually of subjectivity and the limited familiarity of evaluators with their actual work.

\section{Compensation}

Compensation was generally above average in these companies. Pay tended to be fixed for the consulting staff in all firms, although annual bonuses might ensue. For managers and above, pay was contingent on goal achievement, especially commercially related. Compensation packages also included benefits such as health and life insurance and the use of a company car, computer and mobile phone. In Accenture, Andersen and D\&T pay levels were fairly identical among employees in the same career level, at least for consulting staff. This resulted from equal entry-level salaries and a relatively uniform pattern of career advancement. The contingent component in compensation introduced wider variation that was usually well accepted since it reflected performance differentials. In the other three firms, compensation disparity was more pervasive, as a consequence of their recruiting for all career stages. Individual compensation was inevitably tied to entry negotiations, which depended as much on the personal profiles of training and professional experience as on the conditions of the labour market at that moment. The differentials arising from this process were leading to a latent conflict and uneasiness between consultants:

[compensation] It's somewhat ad hoc. I mean, for each career level it's not defined which are the salary range and fringe benefits for that level. So that sometimes causes ill-feelings because you look around and see a colleague doing the same job getting this and that and you wonder, "Why don't I?" (Senior Consultant, KPMG).

\section{Exit management}

Although Alvesson (2000) emphasises employee retention as a central challenge to consulting firms, it was exit management that emerged as pivotal in these companies, decisively influencing the success of their choices in terms of recruitment and career structure. In the words of Andersen's HR manager, their strategy aimed to “. . . recruit good professionals, develop them and retain them", but top managers across firms agreed that a minimum turnover rate of 15 per cent was necessary for their business

\section{Flexibility through HRM}

341 
PR

37,3

342 model to work. The pyramid structure typically adopted by these companies meant that pursuing a long-term career within the firm was not possible for everyone entering it. Even allowing for the expansion of business, a substantial part of the consulting staff could only remain in the company for a few years, after which their permanence had to be justified by an identifiable share of clients and business. This was not particularly problematic under normal circumstances since university graduates most often sought a first temporary employment in these companies for their reputation as training grounds, and only expected to stay for a while before moving on to a more stable and less absorbing job.

The end result of this system was a relatively high voluntary turnover rate from which all the firms benefited. Accenture and particularly Andersen showed a very directive approach in guiding consultants along their career, which included explicitly encouraging them to leave the company when opportunities to stay became dimmer. The "up-or-out" system was very openly tackled and the performance appraisal process purposefully used to manage people's expectations in a way that made it difficult to tell when people left strictly of their own accord from when they were steered out. This granted these two firms a fair level of control over their turnover, such that when market depression hit, they did not feel it as harshly as their competitors. In turn, PwcConsulting and CGEY had a more passive posture, relying more on consultants' own initiative to leave or to respond to implicit hints. As a result, they were deeply affected when the rate of voluntary departures fell in response to a labour market slow down, having to negotiate employment termination with employees at a relevant financial cost.

\section{The need for different kinds of flexibility}

The ability to compete in a permanently evolving market and satisfy an array of clients with very diverse needs and characteristics requires regular adaptation, reshaping, and restructuring. At the time the study was conducted, all six companies were undergoing or had recently undergone restructuring to more closely reflect the business sectors of their client-portfolio, and offering IT services had become a key feature of their market strategy. Seeking this agility has significant implications to the way management consultancies structure their activities and manage their human resources. Temporary project structures and a cultivated predisposition for change were visible examples of what Sparrow and Marchington (1998) defined as organisational and cognitive flexibilities. In this dynamic environment, pursuing different kinds of flexibility becomes critical to the firms' effective response to change.

As expected, the study of these cases confirmed the importance of functional flexibility in management consulting firms. Individual consultants were expected to adapt to very diverse and variable circumstances, having to work on successive projects for clients in different business sectors and apply different skills and knowledge. They also worked on various locations, in different teams and under different supervisors, thus requiring considerable versatility and continuous learning and adapting.

Numerical flexibility also played a crucial role in these firms highly dependent on market conditions. The size and profile of their workforce was directly related to the number and kind of projects sold. The increasing proportion of IT consultants recruited illustrated this point. Moreover, as described above, the regular business 
model based on a pyramid structure required the operation of an "up-or-out" system with a minimum level of employee turnover in order to allow consultants to keep moving up the career ladder. Because there was not room for everybody to stay on, some must leave to allow new junior consultants to enter.

Nevertheless, these firms used only the typical full-time permanent contract for employing their consultants, and rejected the use of short-term and precarious employment contracts that are generally associated with low skilled jobs and equated with numerical flexibility (Felstead and Gallie, 2004). Their policies with regard to employment contracts were usually mandated at an international level and justified in terms of the exemplar behaviour these firms must present to their clients (seen as especially important in firms combining auditing with consulting, or coming from that tradition) and investors (particularly in the publicly held companies). All firms were aiming to be an employer of choice, signalling to current and prospective employees that the firm was committed to the development of a long-term employment relationship.

Time flexibility, commonly considered a facet of numerical flexibility, seemed here more closely related to the attitudes and expectations that lead to functional flexibility. Overtime was pervasive at project peaks, and it tended to be compensated by leaving early or having days off at less busy times. This was invariably done on an informal basis. Part-time jobs were not formally rejected but were marginal and only used at the employees' request.

\section{Flexibility through HRM}

The fact that these firms must explore different kinds of flexibility at the same time does not come as a surprise. What seems novel in face of the available theory is the way in which they simultaneously achieved types of employment flexibility that tend to be seen as essentially incompatible. Unlike segmentation theory models, the companies studied did not favour one kind of flexibility over another. Although they could clearly be classified as aiming at the primary segment of the labour market and sophisticated HRM systems supported an internalised employment mode, numerical flexibility was still indispensable and not compensated by functional flexibility. In contrast with what is suggested by the flexible-firm model, these companies did not resort to segmenting their workforces into a privileged core and a precarious periphery in order to benefit from both kinds of flexibility. In fact, the use of flexible employment contracts did not feature among these firms' repertoire. Nor did they use "human resource portfolios", using different work arrangements to attain different flexibility goals. As detailed below, functional and numerical flexibilities were achieved through a tightly integrated HRM system that combines a "best-practice" approach with the development of an internal labour market.

\section{Functional flexibility}

As pointed out above, functional flexibility was readily recognised as essential and promoted through various means. In line with what is identified in the literature, these firms attempted to develop internal labour markets, offering attractive career prospects and generous compensation packages within a typical full-time permanent employment contract. Furthermore, they provided ample access to training, diversity in project assignments, guidance and support from supervisors and much encouraged

\section{Flexibility through HRM}

343 
PR

37,3

344 team cooperation. The pursuit of functional flexibility seemed fairly similar among all the firms studied. The smaller D\&T and KPMG were perhaps more dependent on their consultants' versatility, as they had less chance of becoming specialised in a particular service line or business sector.

The high level of functional flexibility was achieved among a workforce that was, for the great part and despite their formal permanent contracts, essentially temporary. The fact that most of these people only expected to stay in the firm for a few years did not stop them from exerting considerable effort in adapting and learning new skills. And the firms, in turn, did not seem to hold back on their training investment nor on providing above average working conditions for consultants who they knew were unlikely to stay long. The explanation for this seems to be that both individuals and firms profited from this mutual dedication. Consultants gained from learning to adapt and acquiring new knowledge and skills for themselves as much as for the benefit of their employer, as they saw their efforts rewarded by having their professional value and employment perspectives greatly enhanced. Firms, on the other hand, sought diverse ends from providing training and good employment conditions. Besides an improved performance from their consultants, firms were attempting to build a reputation as "employers of excellence" and as "training grounds" for management professionals. This too was meant to serve more than one purpose. Securing a steady supply of high quality new job candidates might be the more evident goal. But just as important was the fact that consultants' enhanced employability made it easier for these firms to secure an adequate level of exits.

\section{Numerical flexibility}

The observed need for numerical flexibility in management consulting firms was not a revelation. What is, because it runs counter to most literature to date, is the way in which it was achieved. Rather than resorting to flexible employment contracts or to a core/periphery like segmentation of their workforces, the firms studied here operated "up-or-out" systems to secure the desired level of turnover in more or less open and explicit ways. Baden-Fuller and Bateson (1990) describe this system as the only sustainable promotion policy in a hierarchical structure. Recruiting a large number of new university graduates further enhanced numerical flexibility by balancing the figures for new entrants and the ones leaving the firm. The success of this system relied on the effectiveness of performance appraisal and career management, and the employability afforded to consultants by training and development. The reputation of these firms, regarded as nests of elite professionals, also played a significant part in making the "up-or-out" system work (Kärreman, 2002).

In other words, these firms used, as expected, internalised employment and "best practice" HRM to ensure functional flexibility but also, more surprisingly, numerical flexibility. Thus, the same set of HR practices was used to simultaneously pursue these two seemingly contradictory kinds of flexibility.

The level of control over their numerical flexibility seemed to differ among firms. The more open, directive and concerted approaches of Accenture and Andersen afforded them a greater level of control over employee turnover. Their more active involvement in managing consultants' careers allowed them to have a say on whether individuals would progress within the company, or rather leave to take on other challenges and opportunities outside. The more passive postures and less integrated 
implementation of HRM policies observed in the remaining firms rendered them less able to control their numerical flexibility. They were more dependent on individuals' own initiative, which was in turn influenced by outside labour market conditions.

This simultaneous pursuit of functional and numerical flexibility seemed conditional on the level of internal integration of HRM policies and practices (Legge, 1995). Accenture and Andersen were particularly successful at combining their recruiting choices, training efforts, performance appraisal, career supervision and exit management in such a way that they were mutually reinforcing. These practices worked as a tight package, reinforcing the notion of an "HR bundle" (MacDuffie, 1995). Other firms, while basically following the same kind of HR policies seemed unable to achieve the necessary level of coordination among them. D\&T lacked the size to limit their hiring to junior positions and maintain uniform career advancement. CGEY lacked an overall organisational unity and suffered from very diverse policy implementations. Only KPMG did not necessarily mean to develop the model described above. With an organisational structure resembling a diamond rather than a pyramid, this company was less dependent on the career cycle associated with the "up-or-out" system. Nevertheless, and due to its still smaller size, KPMG had a fairly integrated set of HR practices.

\section{Conclusions}

Following a qualitative methodology, six management consulting firms were studied in order to explore the relationship between flexibility and HRM. The major finding of this study is that numerical and functional flexibilities can be simultaneously and interdependently achieved by implementing a single HRM system for the whole workforce. Management consultancies seemed to be able to secure numerical flexibility despite the extensive use of full-time permanent employment contracts. And a high level of functional flexibility was achieved among a workforce that is partly temporary. Both flexibilities result from the integrated implementation of a commitment-based HRM system.

All the firms studied sought to develop internal labour markets with attractive and clearly defined career opportunities, extensive training and above average compensation packages, including a performance based component. Staffing was highly selective, performance was regularly and systematically assessed, teamwork was pervasive, and autonomy and responsibility were encouraged, all of which are identified with "best practice" HRM (Huselid, 1995; MacDuffie, 1995; Delery and Doty, 1996). Functional flexibility was to be expected here, even though it was achieved among employees that only stayed in the organisation temporarily. They were willing to make such an effort because it boosted their own professional value. Thus, in addition to improve firm performance and adaptability, such an HRM system also granted employees enhanced employability. For the firms this meant not only the ability to attract new recruits, but also and most importantly, the opportunity to manage their turnover rates. Two firms were identified as being particularly successful in combining functional and numerical flexibilities. Andersen and Accenture stood out from their counterparts for implementing a particularly well coordinated set of HR policies and practices based on an "up-or-out" philosophy, which consisted of recruiting mostly to the base of the pyramid in large numbers, providing uniform access to training and project assignments, reinforcing this with homogeneous

\section{Flexibility through HRM}

345 
PR

37,3

346 compensation, and using performance appraisal to manage consultants' careers and legitimise promotion or dismissal decisions. The importance of internal integration of HRM policies and practices is, therefore, reinforced. Drawing on the notions suggested by Boxall and Steeneveld (1999), it seemed that while taking on the "right kind" of policies and practices was a condition of ongoing viability, it was the ability to implement HR policies and practices synergistically that seemed to constitute the basis for competitive advantage. For management consulting multinationals this suggests that formal definition of HRM policies at international level should be followed by a more standardised local implementation.

This study offers some new insights in the way organisations can effectively combine functional and numerical flexibility, but the generalisation of the results is limited. Future research should look at other sectors of activity, both in the service and manufacturing sectors. Even within the management consultancy sector the applicability of this model to small and medium sized organisations is questionable. An overall picture of the sector could be better drawn from a large-scale survey, which might also allow for comparisons with other industrial sectors. Finally, the impact of employment flexibility and HRM practices on firm performance remains an exciting research avenue. The material gathered in this study showed that some firms were better than others at combining functional and numerical flexibility. Whether that ability to combine different types of flexibility and manage the "up-or-out" system is positively translated on the overall firm performance is a challenging question to researchers in the field.

\section{References}

Alvesson, M. (2000), "Social identity and the problem of loyalty in knowledge-intensive companies", Journal of Management Studies, Vol. 37 No. 8, pp. 1101-23.

Arthur, J.B. (1994), "Effects of human resource systems on manufacturing performance and turnover", Academy of Management Journal, Vol. 37 No. 3, pp. 670-87.

Atkinson, J. (1987), "Flexibility or fragmentation? The United Kingdom labour market in the eighties", Labour \& Society, Vol. 12 No. 1, pp. 87-105.

Baden-Fuller, C. and Bateson, J. (1990), "Promotion strategies for hierarchically organised professional service firms: is 'up or out' always the best?", International Journal of Service Industry Management, Vol. 1 No. 3, pp. 62-78.

Beyers, W.B. and Lindahl, D.P. (1999), "Workplace flexibilities in the producer services", The Service Industries Journal, Vol. 19 No. 1, pp. 35-60.

Blyton, P. and Morris, J. (1992), "HRM and the limits of flexibility", in Blyton, P. and Turnbull, P. (Eds), Reassessing Human Resource Management, Sage Publications, London, pp. 116-30.

Boxall, P. and Steeneveld, M. (1999), "Human resource strategy and competitive advantage: a longitudinal study of engineering consultancies", Journal of Management Studies, Vol. 36 No. 4, pp. 443-63.

Brewster, C. (1998), "Flexible working in Europe: extent, growth and the challenge of HRM", in Sparrow, P.R. and Marchington, M. (Eds), Human Resource Management: The New Agenda, Financial Times/Pitman Publishing, London, pp. 245-58.

Brown, R.K. (1997), "Flexibility and security: contradictions in the contemporary labour market", in Brown, R.K. (Ed.), The Changing Shape of Work, Macmillan Press, London, pp. 69-86. 
Cappelli, P. and Neumark, D. (2004), "External churning and internal flexibility: evidence on the functional flexibility and core-periphery hypotheses", Industrial Relations, Vol. 43 No. 1, pp. $148-82$.

Delery, J.E. and Doty, D.H. (1996), "Modes of theorizing in strategic human resource management: tests of universalistic, contingency, and configurational performance predictions", Academy of Management Journal, Vol. 39 No. 4, pp. 802-35.

Doorewaard, H. and Meihuizen, H.E. (2000), "Strategic performance options in professional service organisations”, Human Resource Management Journal, Vol. 10 No. 2, pp. 39-57.

Eisenhardt, K.M. (1989), "Building theories from case study research", Academy of Management Review, Vol. 14 No. 4, pp. 532-50.

Felstead, A. and Gallie, D. (2004), "For better or worse? Non-standard jobs and high involvement work systems", International Journal of Human Resource Management, Vol. 15 No. 7, pp. 1293-316.

Friedrich, A., Kabst, R., Weber, W. and Rodehuth, M. (1998), "Functional flexibility: merely reacting or acting strategically?”, Employee Relations, Vol. 20 No. 5, pp. 504-23.

Gallie, D. and White, M. (1994), "Employer policies, employee contracts, and labour-market structure", in Rubery, J. and Wilkinson, F. (Eds), Employer Strategy and the Labour Market, Oxford University Press, Oxford, pp. 69-110.

Geary, J.F. (1992), "Employment flexibility and human resource management: the case of three American electronic plants", Work, Employment and Society, Vol. 6 No. 2, pp. 251-70.

Gooderham, P.N. and Nordhaug, O. (1997), "Flexibility in Norwegian and UK firms: competitive pressure and institutional embeddedness", Employee Relations, Vol. 19 No. 6, pp. 568-80.

Guest, D. (2001), "Human resource management: when research confronts theory", International Journal of Human Resource Management, Vol. 12 No. 7, pp. 1092-106.

Gummesson, E. (1991), Qualitative Methods in Management Research, Sage Publications, Newbury Park, CA.

Gunnigle, P. and Moore, S. (1994), "Linking business strategy and human resource management: issues and implications", Personnel Review, Vol. 23 No. 1, pp. 64-84.

Holland, P.J., Hecker, R. and Steen, J. (2002), "Human resource strategies and organisational structures for managing gold-collar workers", Journal of European Industrial Training, Vol. 26 Nos 2-4, pp. 72-80.

Hunter, L., McGregor, A., MacInnes, J. and Sproull, A. (1993), "The 'flexible firm': strategy and segmentation”, British Journal of Industrial Relations, Vol. 31 No. 3, pp. 383-405.

Huselid, M.A. (1995), "The impact of human resource management practices on turnover, productivity and corporate financial performance", Academy of Management Journal, Vol. 38 No. 3, pp. 635-72.

Kalleberg, A.L. (2001), "Organizing flexibility: the flexible firm in a new century", British Journal of Industrial Relations, Vol. 39 No. 4, pp. 479-504.

Kärreman, D. (2002), "Brand new world? The management of meaning through branding in a knowledge-intensive firm", paper presented at the II EURAM Conference, Stockholm, 9-11 May.

Knox, A. and Walsh, J. (2005), "Organisational flexibility and HRM in the hotel industry: evidence from Australia”, Human Resource Management Journal, Vol. 15 No. 1, pp. 57-75.

Larsen, H.H. and Mayrhofer, W. (2006), Managing Human Resources in Europe, Routledge, London. 
PR

37,3

348
Laursen, K. and Mahnke, V. (2001), "Knowledge strategies, firm types, and complementarity in human-resource practices", Journal of Management and Governance, Vol. 5, pp. 1-27.

Legge, K. (1995), Human Resource Management: Rhetorics and Realities, Macmillan Press, Basingstoke.

Legge, K. (1998), "Flexibility: the gift-wrapping of employment degradation?", in Sparrow, P.R. and Marchington, M. (Eds), Human Resource Management: the New Agenda, Financial Times/Pitman Publishing, London, pp. 286-95.

Lepak, D.P. and Snell, S.A. (1999), "The human resource architecture: toward a theory of human capital allocation and development", Academy of Management Review, Vol. 24 No. 1, pp. 31-48.

MacDuffie, J.P. (1995), "Human resource bundles and manufacturing performance: organizational logic and flexible production systems in the world auto industry", Industrial and Labour Relations Review, Vol. 48 No. 2, pp. 197-221.

MacInnes, J. (1988), “The question of flexibility”, Personnel Review, Vol. 17 No. 3, pp. 12-15.

Marchington, M. and Grugulis, I. (2000), "Best practice' human resource management: perfect opportunity or dangerous illusion?”, International Journal of Human Resource Management, Vol. 11 No. 6, pp. 1104-24.

Matusik, S.F. and Hill, C.W.L. (1998), "The utilization of contingent work, knowledge creation, and competitive advantage", Academy of Management Review, Vol. 23 No. 4, pp. 680-97.

Mayne, L., Tregaskis, O. and Brewster, C. (1996), "A comparative analysis of the link between flexibility and HRM strategy", Employee Relations, Vol. 18 No. 3, pp. 5-24.

O'Reilly, J. (1992), "Banking on flexibility: a comparison of the use of flexible employment strategies in the retail banking sector in Britain and France", International Journal of Human Resource Management, Vol. 3 No. 1, pp. 35-58.

Pollert, A. (1988), “The ‘flexible firm': fixation or fact?”, Work, Employment \& Society, Vol. 2 No. 3, pp. 281-316.

Ram, M. (1999), "Managing consultants in a small firm: a case study", Journal of Management Studies, Vol. 36 No. 6, pp. 875-97.

Robertson, M. and Hammersley, G.O. (2000), "Knowledge management practices within a knowledge-intensive firms: the significance of the people management dimension", Journal of European Industrial Training, Vol. 24 Nos 2-4, pp. 241-53.

Rose, M. (1994), "Level of strategy and regimes of control", in Rubery, J. and Wilkinson, F. (Eds), Employer Strategy and the Labour Market, Oxford University Press, Oxford, pp. 138-71.

Rubery, J. (1994), "Internal and external labour markets: towards an integrated analysis", in Rubery, J. and Wilkinson, F. (Eds), Employer Strategy and the Labour Market, Oxford University Press, Oxford, pp. 37-68.

Sisson, K. and Storey, J. (2000), The Realities of Human Resource Management: Managing the Employment Relationship, Open University Press, Maidenhead.

Smith, V. (1994), "Institutionalising flexibility in a service sector firm - multiple contingencies and hidden hierarchies", Work and Occupations, Vol. 21 No. 3, pp. 284-307.

Sparrow, P. (1998), "The pursuit of multiple and parallel organizational flexibilities: reconstituting jobs", European Journal of Work and Organizational Psychology, Vol. 7 No. 1, pp. 79-95.

Sparrow, P. and Marchington, M. (1998), "Re-engaging the HRM function - rebuilding work, trust and voice", in Sparrow, P. and Marchington, M. (Eds), Human Resource Management: The New Agenda, Financial Times/Pitman Publishing, London, pp. 296-313. 
Starbuck, W.H. (1992), "Learning by knowledge-intensive firms", Journal of Management Studies, Vol. 29 No. 6, pp. 713-40.

Truss, C., Gratton, L., Hope-Hailey, V., McGovern, P. and Stiles, P. (1997), "Soft and hard models of human resource management: a reappraisal", Journal of Management Studies, Vol. 34 No. 1, pp. 53-73.

Tsui, A.S., Pearce, J.L., Porter, L.W. and Hite, J.P. (1995), "Choice of employee-organization relationship: influence of external and internal organizational factors", Research in Personnel and Human Resource Management, Vol. 13, pp. 117-51.

Walton, R.E. (1985), "From control to commitment in the workplace", Harvard Business Review, March-April, pp. 77-84.

\section{About the authors}

Ana Carvalho is a researcher in the OB-HRM group and assistant professor at the Management Department of the University of Minho, in Portugal. Her research interests include human resource management, flexibility and new organisational forms, voluntary organisations and the management of volunteers.

Carlos Cabral-Cardoso is an associate professor of management and director of the Management Research Unit (NEGE) at the University of Minho, Portugal. His current research interests include the role of the HR function, equal opportunities and diversity, university management and academic careers, and ethical issues in management education. Carlos Cabral-Cardoso is the corresponding author and can be contacted at ccabral@eeg.uminho.pt

To purchase reprints of this article please e-mail: reprints@emeraldinsight.com Or visit our web site for further details: www.emeraldinsight.com/reprints 